\title{
Treatment of patients with pancreatic endocrine tumours using a new long-acting somatostatin analogue symptomatic and peptide responses
}

\author{
S M WOOD, M E KRAENZLIN, T E ADRIAN, AND S R BLOOM \\ From the Department of Medicine, Royal Postgraduate Medical School, Hammersmith Hospital, London
}

SUMmARY Seven patients with gut and pancreatic endocrine tumours have been treated with a long acting somatostatin analogue (SMS 201-995), given as a twice daily subcutaneous injection. This produced dramatic improvement in their endocrine related symptoms, in association with a fall in circulating tumour peptides. One of these patients has now been treated for seven months with this analogue which has controlled his previously life threatening diarrhoea caused by a malignant VIP secreting tumour. He gives his own injections twice daily, and has returned to a full and active life. This is a promising agent both for acute treatment of peptide hypersecretion, and for the long term management of some patients who are unresponsive to other available therapy.

Pancreatic and gut endocrine tumours secrete high concentrations of peptides and amines, which may have life threatening clinical and biochemical consequences. ${ }^{1-4}$ Somatostatin, a potent endogenous inhibitor of peptide release can be used in the treatment of patients with peptide secreting tumours. ${ }^{5-9}$ Its native form, however, has the disadvantage of a short half life, necessitating intravenous administration. ${ }^{10}$ Analogues of this peptide have therefore been developed to overcome these problems, ${ }^{11}$ and have been used with some success in the short term treatment of peptide hypersecretory syndromes. ${ }^{12}$ Recently an octapeptide analogue of somatostatin, SMS 201-995 (Sandoz) (Fig. 1) has been developed with a prolonged duration of action, and has been shown to have some selectivity of action, at least in animals. ${ }^{13}$ It can be used subcutaneously, or even orally at high doses. We report here the results of a study to investigate the use of this analogue in the acute and long term treatment of a variety of pancreatic endocrine tumours.

\section{Methods}

PATIENTS

Seven patients, one with carcinoid syndrome, and

Address for correspondence: Dr S M Wood, 2nd Floor Francis Fraser Laboratories, Royal Postgraduate Medical School. Hammersmith Hospital, Du Cane Road, London W12 0HS.

Received for publication 28 June 1984 six with peptide secreting pancreatic endocrine tumours were studied. The latter group consisted of two pure gastrinomas, two tumours secreting both gastrin and glucagon and two secreting vasoactive intestinal polypeptide (VIP), with peptide histidine isoleucine (PHI) and neurotensin. The six patients with metastatic disease had had clinically apparent tumours for several years, and had been treated over this period with chemotherapy, and or hepatic artery embolisation. In one patient with a VIP secreting tumour surgical excision of the primary tumour, a recurrence, and subsequently of the metastases, had been attempted. In all these cases only temporary remission of symptoms had occurred. The major clinical features of these patients at the time of the study are recorded in the Table. In most cases these were those expected of the particular hypersecretory syndrome; however, symptoms and signs had been modified to some extent by prior treatment and medication, which in some cases was essential to continue for the safety of the patients. Thus patients with gastrinomas were maintained on their previous dose of $\mathrm{H}_{2}$-antagonist, cimetidine, and some on insulin. Patients with glucagon secreting tumours were given prophylactic therapy for thromboembolism (aspirin or dipyridamole). Fluid and electrolyte replacement was given when required.

TEST PROCEDURE

All patients were admitted to the metabolic unit. 
Somatostatin:

H-Ala - Gly-Cys-Lys-Asn-Phe-Phe-Trp-Lys-Thr-Lys-Thr-Phe-Thr-Ser-Cys-OH

SMS-201-995:

H- (D) Phe -Cys-Phe- (D) Trp - Lys - Thr - Cys - Thr - ol, acetate

Fig. 1 Amino acid sequences of somatostatin and SMS 201-995.

Over the first 48 hours pretreatment symptoms were monitored, and blood samples for gut hormones collected, under basal fasting conditions, as well as after a standard test breakfast. This consisted of white bread (60 g), jam (35 g), butter (5 g) eggs (2) and unsweetened orange juice $(150 \mathrm{ml})$, containing $20 \mathrm{~g}$ protein, $22 \mathrm{~g}$ fat, $67 \mathrm{~g}$ carbohydrate, with a total calorific content of $530 \mathrm{Kcal}$. On the subsequent three days each patient was given SMS 201-995 (50 $\mu \mathrm{g})$ subcutaneously twice daily, 15 minutes before breakfast, then approximately 12 hours later, 15 minutes before supper. Symptoms and side effects were monitored, and blood samples collected for gut hormones throughout each day, and after two standard breakfasts given after the first and fifth doses of SMS. On the final two days symptoms and peptides were monitored after withdrawal of SMS treatment. Blood pressure, pulse, temperature, and urine analysis were monitored throughout the study.

Blood samples for gut hormones and glucose were collected into chilled heparinised tubes containing aprotonin (Trasylol, Bayer) $400 \mathrm{KIU} / \mathrm{ml}$ blood, centrifuged within 15 minutes of sampling, the plasma removed and stored at $-20^{\circ} \mathrm{C}$ before assay.

Urine for measurement of 5-hydroxyindole acetic acid was collected over 24 hours by the patient with the carcinoid syndrome, before, during and after treatment with SMS.

Haemoglobin, white cell count, urea, creatinine, electrolytes and liver function were monitored on all patients.

\section{RADIOIMMUNOASSAY AND CHROMATOGRAPHIC} ANALYSIS

Gut hormones were measured by well established radioimmunoassays using specific rabbit antisera and ${ }^{125}$ I labelled synthetic peptide. ${ }^{14}$ There was no significant cross reaction between any of the peptides assayed. To investigate the influence of treatment on molecular heterogeneity of some of the tumour secreted gut hormones, in particular VIP, plasma samples were subjected to gel

Table Clinical features of the tumours

\begin{tabular}{|c|c|c|c|c|c|c|}
\hline Patients & Sex & Age & Tumour type & Main clinical features & Previous treatment & Raised peptides (pmol/l) \\
\hline 1 & $\mathbf{M}$ & 43 & $\begin{array}{l}\text { VIPoma } 1977 \\
\text { (multiple mets) }\end{array}$ & $\begin{array}{l}\text { Severe watery diarrhoea, } \\
\text { dehydration, hypokalaemia }\end{array}$ & $\begin{array}{l}\text { Streptozotocin } \\
\text { Hepatic artery } \\
\text { embolisation }\end{array}$ & $\begin{array}{l}\text { VIP } 180-360(\mathrm{~N}<30) \\
\text { Neurotensin } 250-380 \\
(\mathrm{~N}<200)\end{array}$ \\
\hline 2 & $\mathbf{F}$ & 47 & $\begin{array}{l}\text { VIPoma } 1980 \\
\text { (multiple mets) }\end{array}$ & $\begin{array}{l}\text { Severe watery diarrhoea, } \\
\text { dehydration, hypokalaemia, } \\
\text { abdominal pain }\end{array}$ & $\begin{array}{l}3 \text { surgical resections, } \\
1980-1982 \\
\text { Streptozotocin, hepatic } \\
\text { artery embolisation } \\
1982-1983\end{array}$ & $\begin{array}{l}\text { VIP } 214-360(\mathrm{~N}<30) \\
\text { PHI } 300-400(\mathrm{~N}<50)\end{array}$ \\
\hline 3 & $\mathbf{M}$ & 72 & $\begin{array}{l}\text { Gastrinoma } 1981 \\
\text { (multiple mets) }\end{array}$ & $\begin{array}{l}\text { Epigastric pain/distension } \\
\text { Diarrhoea/steatorrhoea }\end{array}$ & $\begin{array}{l}\text { Hepatic artery } \\
\text { embolisation } 1982 \\
\text { Cimetidine ( } 3 \text { g/day) } 1981\end{array}$ & Gastrin $100-150(\mathrm{~N}<40)$ \\
\hline 4 & $\mathbf{M}$ & 49 & $\begin{array}{l}\text { Gastrinoma } 1982 \\
\text { (no mets) }\end{array}$ & $\begin{array}{l}\text { Epigastric pain } \\
\text { Diarrhoea/steatorrhoea }\end{array}$ & Cimetidine ( $4 \mathrm{~g} /$ day) 1982 & Gastrin $120-270(\mathrm{~N}<40)$ \\
\hline 5 & $\mathbf{M}$ & 72 & $\begin{array}{l}\text { Glucagonoma/gastrinoma } \\
1981 \text { (multiple mets) }\end{array}$ & $\begin{array}{l}\text { Diabetes (on insulin), rash } \\
\text { controlled on } \mathrm{Zn} \mathrm{SO}_{4}\end{array}$ & $\begin{array}{l}\text { Hepatic artery } \\
\text { embolisation } 1981\end{array}$ & $\begin{array}{l}\text { Glucagon } 1000-1500 \\
(\mathrm{~N}<50) \\
\text { Gastrin } 100-120(\mathrm{~N}<40)\end{array}$ \\
\hline 6 & $\mathbf{M}$ & 65 & $\begin{array}{l}\text { Glucagonoma/gastrinoma } \\
1981 \text { (multiple mets) }\end{array}$ & $\begin{array}{l}\text { Diabetes (on insulin), rash } \\
\text { controlled on } \mathrm{ZnSO}_{4}\end{array}$ & $\begin{array}{l}3 \text { hepatic artery } \\
\text { embolisations, } \\
\text { Streptozotocin } 1982\end{array}$ & $\begin{array}{l}\text { Glucagon } 600-1000(\mathrm{~N}<50) \\
\text { Gastrin } 60-80(\mathrm{~N}<40)\end{array}$ \\
\hline 7 & $\mathbf{F}$ & 68 & Carcinoid syndrome 1980 & $\begin{array}{l}\text { Diarrhoea, flushing } \\
\text { Valvular involvement }\end{array}$ & $\begin{array}{l}2 \text { hepatic artery } \\
\text { embolisations 1981-1982 } \\
\text { Methysergide } \\
\text { P chlorophenylalanine }\end{array}$ & $\begin{array}{l}\text { 5HIAA } 150-220 \text { (N } 16-90 \\
\mu \mathrm{mol} / 24 \mathrm{~h})\end{array}$ \\
\hline
\end{tabular}


permeation chromatography, using a Sephadex G-50 column, calibrated with dextran blue, cytochrome $\mathrm{C},{ }^{125}$ I labelled synthetic peptide and $\mathrm{Na}^{125} \mathrm{I}$, and coeluted with $0.06 \mathrm{M}$ phosphate EDTA buffer (pH 7.4) and $0.2 \mathrm{M} \mathrm{NaCl}$, containing $70 \mu \mathrm{M}$ human serum albumin.

\section{Results}

\section{ACUTE TREATMENT - SYMPTOMS}

Diarrhoea was a feature common to all patients, irrespective of their tumour type; and in all but one, this was improved by SMS, as shown by Figure 2, which shows stool frequency before and after 48 hours of treatment. These patients had previously been treated with a variety of antidiarrhoeal agents, none of which had been effective. Stool consistency varied considerably in the different hypersecretory syndromes; the patients with high levels of circulating VIP had large volume liquid stools (4-8 $1 /$ day), in most cases almost like water with the occasional fleck of solid material. In both these patients SMS resulted in semi-formed stools, within 48 hours of treatment, and reduced stool volume to less than $500 \mathrm{ml} /$ day. Profuse watery diarrhoea returned within 36 hours of withdrawal of SMS. A similar response was observed in the patient with the carcinoid syndrome. Patients with high circulating gastrin or glucagon had loose, but not watery stools; steatorrhoea was intermittently present in the two patients with pure gastrinomas. Stool form became normal on treatment with SMS. Relief of other symptoms was less striking, the two patients who previously complained of epigastric pain, despite treatment with $\mathrm{H}_{2}$-receptor antagonists, reported disappearance of pain during treatment with SMS. The patient with carcinoid syndrome reported

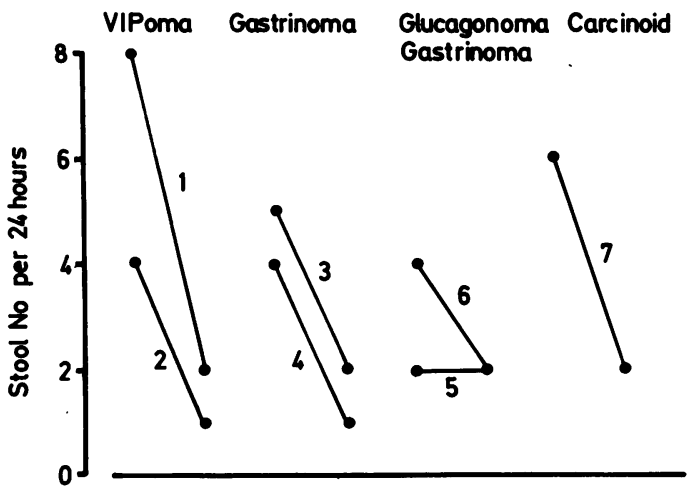

Fig. 2 Stool frequency before and after 48 hours of SMS 201-995 (50 $\mu \mathrm{g} \mathrm{sc}, \mathrm{bd})$. slightly fewer hot flushes, there was no change in the depth of her long standing cutaneous erythema. Both patients with glucagon secreting tumours had required insulin for some years before the study, SMS neither improved their glucose tolerance, nor reduced their insulin dosage requirement. No hypoglycaemic episodes occurred in either of these patients during treatment. Necrolytic migratory erythema was not a prominent feature of their disease at the time of the study, and was not altered by SMS.

All patients tolerated SMS well, the only side effect seen was in the patient (no. 5 on the Table), whose tumour secreted both gastrin and glucagon. This patient regularly experienced postural hypotension as a consequence of diabetic autonomic neuropathy, this was worsened by SMS; however halving the dose to $25 \mu \mathrm{g}$ twice per day resolved the problem.

\section{GUT HORMONES}

Vasoactive intestinal polypeptide fell by more than $50 \%$ in both patients with VIP secreting tumours, however the lowest values reached were still 4-8 times higher than the upper limit of normal for this peptide (Fig. 3). The discrepancy between the

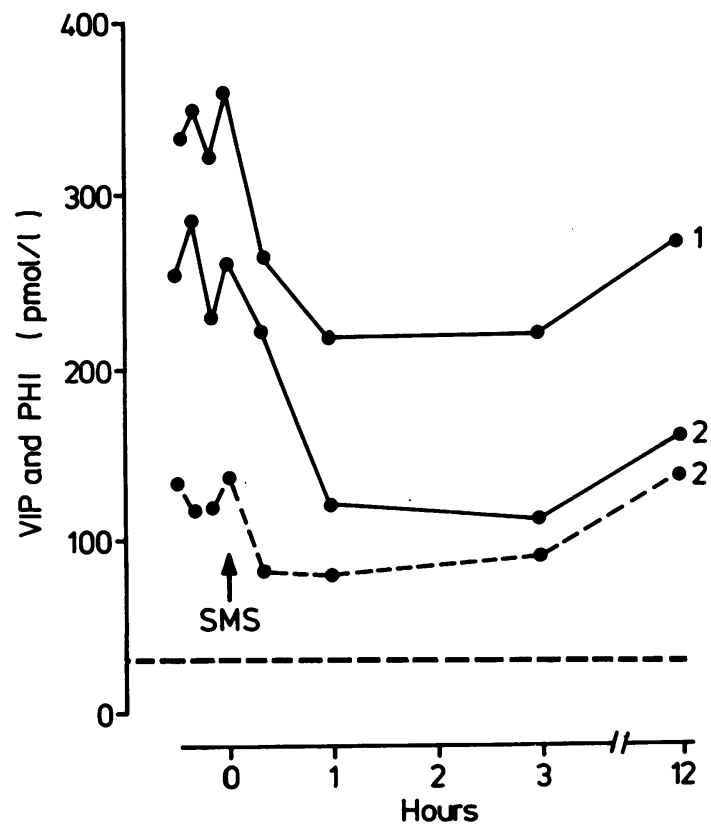

Fig. 3 Plasma VIP (solid line) and PHI (dotted line) for 12 hours after SMS 201-995 in two patients with VIP secreting tumours. Dotted horizontal line indicates the upper limit of normal for plasma VIP. 
clinical and hormone responses was possibly explained by the findings of column chromatography. Figure 4 shows the chromatographic profile of VIP before and during treatment with SMS; before SMS several large molecular forms of VIP were present in the circulation, in addition to the peptide which coeluted with standard VIP. During treatment the standard form disappeared from the plasma leaving only larger VIP-like peptides, which may have had lower biological activity. Of the other peptides cosecreted by these vipomas, plasma peptide histidine isoleucine fell slightly (Fig. 3), while there was no change in plasma neurotensin during treatment.

In those patients with raised plasma gastrin concentrations this fell rapidly after SMS as shown in Figure 5. Pretreatment values varied considerably between patents but this did not appear to influence the response to SMS, which lowered gastrin by

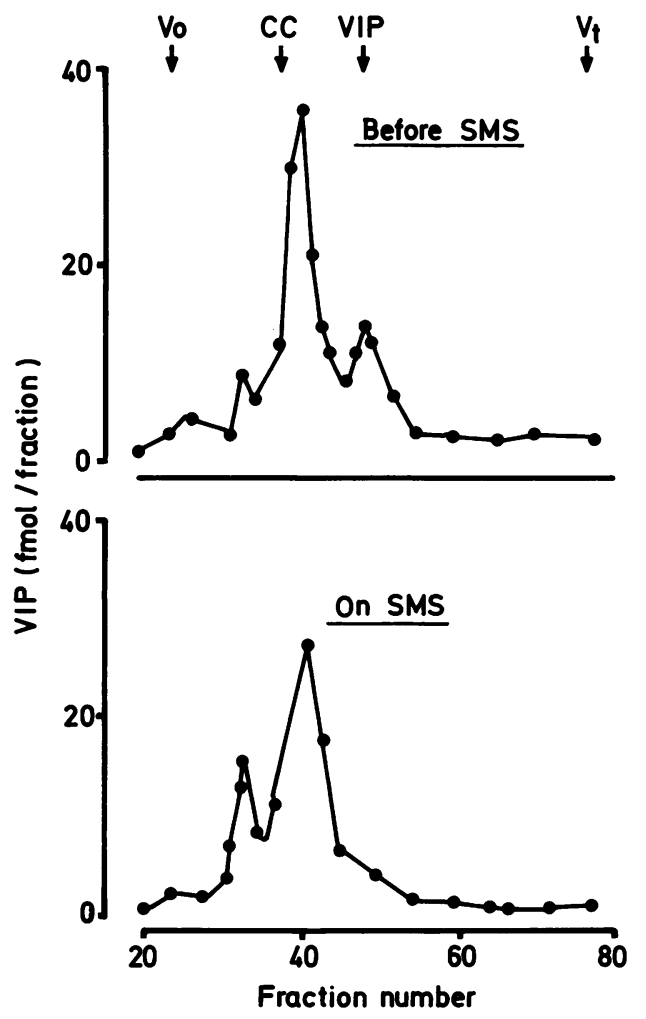

Fig. 4 Column chromatographic profile of VIP in plasma of patient 1 before, and after SMS. Dextran blue (Vo), Cytochrome C (CC), 125 I-labelled VIP (VIP) and Na 125 I $(V t)$ were the molecular size markers. Note smaller form of VIP disappears on SMS.

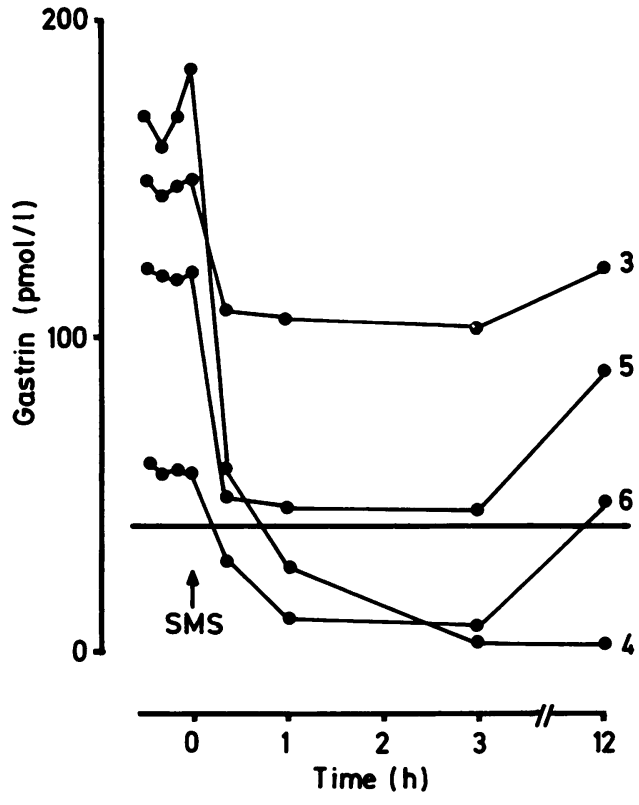

Fig. 5 Plasma gastrin for 12 hours after SMS 201-995 in two patients with gastrin secreting tumour $(3,4)$ and two also secreting glucagon $(5,6)$. Dotted line indicates upper limit of normal for plasma gastrin.

$30-100 \%$. The greatest and most prolonged suppression of gastrin release occurred in the only patient without metastatic disease (no 4 in Fig. 5 and Table).

Both patients with glucagon secreting tumours had extremely high circulating concentrations of glucagon, which fell precipitously after SMS, to values just above normal (Fig. 6).

In most patients there was a tendency for the peptide concentrations to rise again by the time of the next dose of SMS, 12 hours from the first. Plasma glucagon in patient 5 , and gastrin in patient 6 , had virtually returned to pretreatment values by this time, whereas plasma glucagon in the latter patient, and plasma gastrin in patient 4 remained low throughout. Other patients showed patterns falling between these two extremes. Inhibition of tumour secreted peptides followed a similar pattern over the three days of treatment, there was no evidence of either a greater or lesser effect with repeated doses of SMS. After withdrawal of SMS most peptide concentrations returned to pretreatment values, in the case of the patients with VIP secreting tumours there was an overswing of secretion, with higher values for about 24 hours.

SMS lowered basal gut hormone concentrations and produced a marked suppression of their 


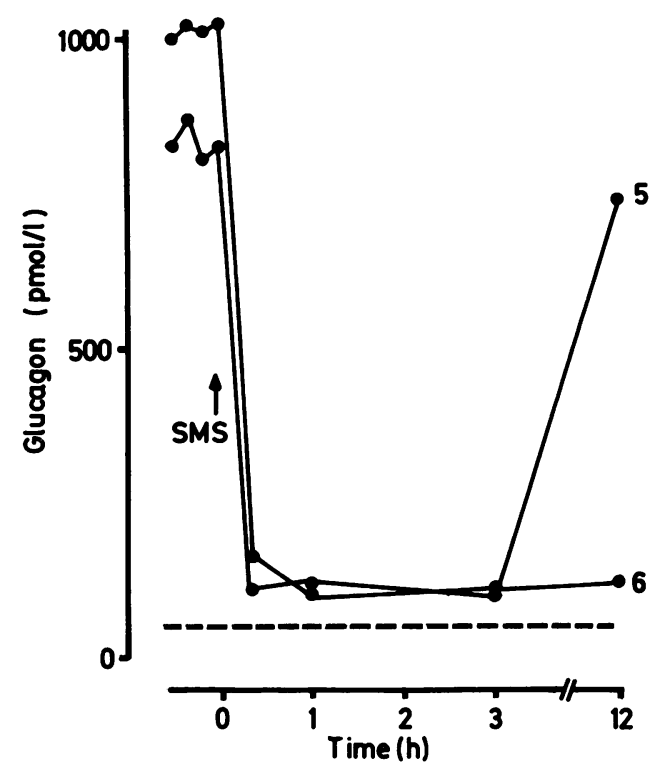

Fig. 6 Plasma glucagon for 12 hours after SMS 201-995 in two patients with glucagon and gastrin secreting tumours. Dotted line indicates the upper limit of normal for plasma glucagon.

postprandial release (Fig. 7). Despite total inhibition of food stimulated insulin secretion, glucose tolerance was little affected. Indeed there was an initial impaired rise in plasma glucose.

SMS did not lower 24 hour urinary 5hydroxyindole acetic acid concentrations in the patient with carcinoid syndrome.

Haematological, electrolyte, and liver function were not altered by SMS. Similarly pulse and blood pressure measurements remained stable for each patient throughout treatment, except in patient 5, whose pretreatment postural hypotension was worsened by SMS.

\section{LONG TERM TREATMENT}

At the time of this study, patient 1 , a 43 year old man with a malignant VIP secreting tumour diagnosed in 1977, developed recurrence of severe watery diarrhoea and hypokalaemia having been in total symptomatic and biochemical remission over the preceeding five years after chemotherapy with streptozotocin. Attempts were made to induce a second remission with streptozotocin and 5fluorouracil, and then with hepatic artery embolisation. Neither method was effective, and it became increasingly difficult to control his diarrhoea and consequent dehydration and hypokalaemia, which necessitated continuous intravenous fluid and
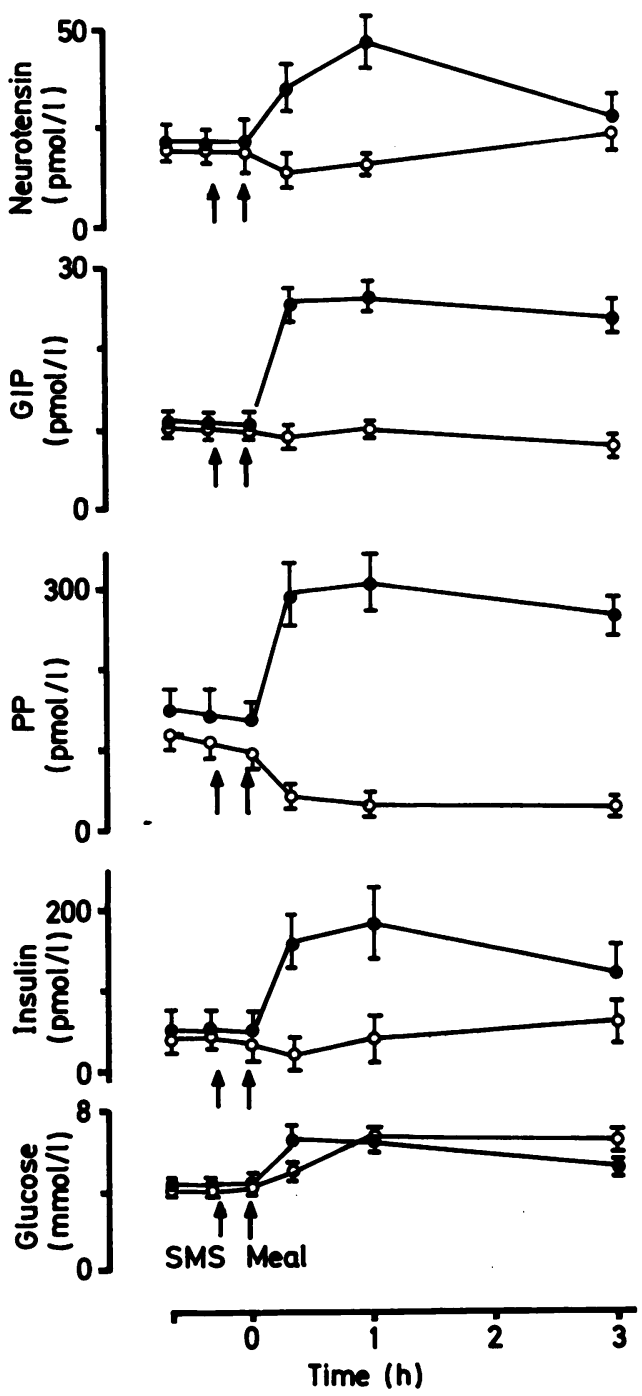

Fig. 7 Mean plasma hormone and glucose concentrations after a standard meal in the presence $(\bigcirc)$ and absence $(O)$ of SMS 201-995.

electrolyte replacement. Treatment with SMS resulted in a marked improvement of diarrhoea, in association with a reduction in circulating VIP (Figs. 3 and 4). Withdrawal of SMS led to recurrence of severe symptoms. As no other therapeutic alternatives were available, we have treated this patient for the last seven months with twice daily subcutaneous SMS $(50 \mu \mathrm{g})$, which he administers himself, as an outpatient. He has had no recurrence of diarrhoea, and has been able to return to full time work, and to his long standing hobby of marathon 
running (10-20 miles per day). Although the plasma VIP concentration over this time has remained raised, with a mean value of $161 \pm 68 \mathrm{pmol} / \mathrm{l}$, this is substantially lower than before treatment $(361 \pm 19$ $\mathrm{pmol} / \mathrm{l})$, VIP immunoreactivity is now present in the large form which may be of reduced biological activity (Fig. 4).

\section{Discussion}

The clinical and biochemical manifestations of the gut and pancreatic endocrine tumours are determined by the peptides and amines secreted by these tumours. ${ }^{1-4}$ In contrast to most tumours, morbidity and mortality of these endocrine tumours are closely related to the metabolic abnormalities induced by such hormonal hypersecretion..$^{1-3}$ Indeed it is now well recognised that supression of tumour related peptide and amine secretion can produce relatively prolonged symptomatic and biochemical remission, even in the absence of effective treatment to reduce the progression of tumour growth..$^{5-7} 15$ Although such a palliative approach to treatment may be regarded as inadequate on first principles, it assumes greater importance in the context of the malignant behaviour of most of these tumours. Curative surgery is rarely successful, while their response to a variety of chemotherapeutic agents is poor. ${ }^{1216}$ There is therefore a definite place for antisecretory therapy, to be used either, to suppress peptide related metabolic abnormalities while curative treatment is attempted, or in the long term, when this fails.

Little is known about the natural history of peptide secreting tumours. Figures on the long term survival in the Zollinger-Ellison syndrome are available from patients in whom acid hypersecretion has been prevented by total gastrectomy. In these patients with metastatic gastrinomas a five year survival of $42 \%$, and 10 year survival of $30 \%{ }^{17}$ is reported. It has been estimated that only $50 \%$ eventually die from their tumours. ${ }^{17}{ }^{18}$ These figures are no doubt influenced by the substantial morbidity and mortality of total gastrectomy itself, though it is likely that the long term survival resulting from effective treatment of the Zollinger-Ellison syndrome with $\mathrm{H}_{2}$ receptor antagonists, will be even more favourable. Mortality related to these endocrine tumours per se is therefore much lower than that for most malignant disease. This is further supported by the finding that in some patients, glucagon related symptoms antidate the diagnosis of the glucagonoma by some years, suggesting the presence of an occult tumour throughout this time. ${ }^{19}$ There is a suggestion therefore that if peptide hypersecretion is controlled, then patients may have a relatively good long term prognosis despite their malignant disease.

Somatostatin provides a method of directly inhibiting secretion of tumour peptides, and so preventing their detrimental effects. This study shows that a long acting analogue of somatostatin, given subcutaneously, as insulin is routinely selfadministered by diabetics, can produce effective suppression of peptide secretion from a number of pancreatic tumours, and result in marked improvement in patients' symptoms. In the group of patients studied here the alternative methods of treatment, surgery, chemotherapy, and hepatic artery embolisation, had failed, yet despite their apparent end-stage disease these patients responded well to therapy with SMS.

Patients with peptide hypersecretion, with severe metabolic derangements are poor candidates for surgery, chemotherapy, or hepatic artery embolisation. Short term pretreatment with SMS could reverse these metabolic abnormalities and so improve the response to curative therapy, in patients with operable lesions.

SMS caused no significant side effects, either acutely, or during seven months of continuous treatment. Despite suppression of insulin secretion glucose tolerance remained normal, suggesting the inhibitory effect of insulin was counterbalanced, both by inhibition of glucagon secretion and by the known inhibitory effect of somatostatin on glucose absorption. ${ }^{20}$

The mechanism by which SMS produces resolution of peptide related effects is of interest, certainly part of its effect is directly due to inhibition of peptide release. ${ }^{5-7} 12$ It is possible that it also has an effect on peptide processing as in the vipomas there appeared to be preferential inhibition of the small molecular weight form of VIP. A similar phenomenon has been reported for metoclopramide,$^{15}$ and streptozotocin. ${ }^{2}$ Somatostatin, has been shown to directly inhibit gastric acid and intestinal fluid secretion, as well as to stimulate fluid absorption, ${ }^{21-23}$ SMS is likely to have similar effects. This would provide an explanation for resolution of diarrhoea in the carcinoid syndrome when urinary 5-hydroxy-indole acetic acid was not lowered, and contribute to the improvement in symptoms observed in vipomas and gastrinomas.

An exciting new development regarding somatostatin's therapeutic role, stems from the recent finding of shrinkage of hepatic metastases in our patient with the vipoma treated with SMS for seven months. ${ }^{24}$ Somatostatin has been reported to influence cellular turnover in tissues, ${ }^{25} 26$ it therefore may have a future place as a tumour 
shrinking agent in the treatment of endocrine tumours in the same manner as the dopamine agonist bromocryptine is used to treat prolactinomas.

\section{References}

1 Friesen SR. Tumours of the endocrine pancreas. $N$ Engl J Med 1982; 306: 580-90.

2 Wood SM, Polak JM, Bloom SR. Gut hormone secreting tumours. Scand J Gastroenterol 1983; 18: suppl 82: 165-79.

3 Kaplan EL. The carcinoid syndromes. In: Friesen SR, ed. Surgical endocrinology: clinical syndromes. Philadelphia: Lippincott, 1978: 120-47.

4 Robertson JIS, Peart WS, Andrews JM. The mechanism of facial flushes in the carcinoid syndrome. $Q J$ Med 1962; 21: 103-23

5 Bonfils S, Rene E, Piginal F, Rambaud JC. Rebound effect after somatostatin treatment in Verner Morrison syndrome. Lancet 1979; 2: 476.

6 Sohier J, Jeanmougin M, Lombrail P, Passa Ph. Rapid improvement of skin lesions in glucagonomas with intravenous somatostatin infusion Lancet 1980; 1: 40.

7 Dharmsathaphorn K, Sherwin RS, Cataland S, Jaffe B, Dobbins J. Somatostatin inhibits diarrhoea in the carcinoid syndrome Ann Intern Med 1980; 92: 68-9.

8 Gerich JE, Patton GS. Somatostatin. Physiology and clinical application. Med Clin N Am 1978; 62: 375-92.

9 Gyr NE, Kayasseh L, Keller U. Somatostatin as a therapeutic agent. In: Bloom SR, Polak JM, eds. Gut hormones. London: Churchill Livingstone, 1981: 581-5.

10 Sheppard M, Shapiro B, Pimstone B, Kronheim MB, Gregory $\mathrm{M}$. The metabolic clearance and plasma half disappearance time of exogenous somatostatin in man. J Clin Endocrinol Metab 1979; 49: 50-3.

11 Bhathena SJ, Recant L, Meyers LA, Coy DH. Selective inhibition of glucagon and insulin secretion by somatostatin analogues. Proc $R$ Soc Med 1979; 160: 76-9.

12 Long RG, Barnes AJ, Adrian TE, et al. Suppression of pancreatic endocrine tumour secretion by long acting somatostatin analogue. Lancet 1979; 2: 764-7.

13 Bauer W, Briner U, Doepfner W, et al. SMS 201-995: a very potent and selective octapeptide analogue of somatostatin with prolonged action. Life Sci 1982; 31: 1133-40.
14 Multiple authors. In: Bloom SR, Long RG, eds. Radioimmunoassays of gut regulatory peptides London: Saunders, 1982.

15 Long RG, Bryant MG, Yuille PM, Bloom SR. Mixed pancreatic tumour syndrome with symptoms of excess vasoactive intestinal polypeptide and insulin: improvement of diarrhoea with metoclopramide. Gut 1981; 22: 505-11.

16 Moertel CG, Hanley JA, Johnson LA. Streptozotocin alone compared with streptozotocin plus fluorouracil in the treatment of advanced islet cell carcinoma $N$ Engl J Med 1980; 303: 1189-94.

17 Fox PS, Hofmann JW, De Cosse JJ, Wilson SD. The influence of total gastrectomy on survival in malignant Zollinger-Ellison tumours. Ann Surg 1974; 180: 55860.

18 Zollinger RM, Martin EW, Carcy LC, Sparts J, Minton JP. Observations on the postoperative tumour growth behaviour of certain islet cell tumours. Ann Surg 1976: 184: 525-30.

19 Wood SM, Polak JM, Bloom SR. The glucagonoma syndrome. In: Lefebvre P, ed. Handbook of experimental pharmacology VI. Berlin: SpringerVerlag, 1983

20 Johansson $\mathrm{C}$, Wisen $\mathrm{O}$, Efendic S, Uvnas Wallenstein $\mathrm{K}$. Effects of somatostatin on gastrointestinal propagation and absorption of oral glucose in man. Digestion 1981; 22: 126-37.

21 Guandalini S, Kachur JF, Smith PL, Miller RJ, Field $M$. In vitro effect of somatostatin on ion transport in rabbit intestine. Am J Physiol 1980; 238: G67-74.

22 Krejs GJ, Brown R, Raskin P. Effect of intravenous somatostatin on jejunal absorption of glucose, amino acids, water and electrolytes. Gastroenterology 1980; 78: $26-31$

23 Ruskone A, Rene E, Chayvialle JA, et al. Effect of somatostatin on diarrhoea and on small intestinal water and electrolyte transport in a patient with pancreatic cholera. Dig Dis Sci 1982; 27: 459-66.

24 Kraenzlin ME, Ch'ng JLC, Wood SM, Carr DH, Bloom SR. Long-term treatment of a VIPoma with somatostatin analogue resulting in remission of symptoms and possible shrinkage of metastases. Gastroenterology (In press).

25 Lehy $\mathrm{T}$, Dubrasquet $\mathrm{M}$, Brazeau $\mathrm{P}$, Bonfils $\mathrm{S}$. Inhibitory affect of prolonged administration of long acting somatastatin on gastrin stimulated fundic epithelial cell growth in rat. Digestion 1982, 24: 246-55.

26 Morisset J, Genick P, Lord A, Solomon TE. Effect of chronic administration of somatostain on rat exocrine pancreas. Regul Peptides 1982; 4: 49-58. 